\title{
Both acute and chronic near-normoglycaemia are required to improve insulin resistance in Type 1 (insulin-dependent) diabetes mellitus
}

\author{
P.Fasching $^{1}$, K. Ratheiser ${ }^{1}$, P.Damjancic ${ }^{1}$, B. Schneider ${ }^{2}$, P. Nowotny ${ }^{1}$, H. Vierhapper $^{1}$ and W. WaldhäusI $^{1}$ \\ ${ }^{1}$ Department of Medicine III, Division of Endocrinology and Metabolism, University of Vienna, Austria \\ ${ }^{2}$ Institute of Medical Statistics, University of Vienna, Austria
}

\begin{abstract}
Summary. To determine the impact of both short- and longterm "near-normoglycaemia" on insulin resistance in Type 1 (insulin-dependent) diabetes hepatic glucose production $\left(\mathrm{mg} \cdot \mathrm{kg}^{-1} \cdot \mathrm{min}^{-1}\right)$ and peripheral glucose utilisation ("Mvalue", $\left.\mathrm{mg} \cdot \mathrm{kg}^{-1} \cdot \mathrm{min}^{-1}\right)$ were estimated during an euglycaemic hyperinsulinaemic clamp $(10 \mathrm{mU} \cdot \mathrm{kg} \cdot \mathrm{min})$ in patients with either good $\left(\mathrm{HbA}_{1 c}<5.8 \%\right.$, groups $\mathrm{A}$ and $\left.\mathrm{B}\right)$ or poor $\left(\mathrm{HbA}_{1 \mathrm{c}}>7.5 \%\right.$, groups $\mathrm{C}$ and $\left.\mathrm{D}\right)$ long-term metabolic control (time $>12$ months) and in healthy subjects ( $\mathrm{HbA}_{1 \mathrm{c}}$ : $5.08 \pm 0.20 \% ; n=8)$. To this end blood glucose was stabilized at $6.7 \mathrm{mmol} / 1$ by overnight $(\mathrm{t}=12 \mathrm{~h})$ i.v. regular insulin in groups $\left(n=8\right.$ each) $\mathrm{A}\left(\mathrm{HbA}_{1 \mathrm{c}}: 5.49 \pm 0.46 \%\right)$ and $\mathrm{C}\left(\mathrm{HbA}_{1 \mathrm{c}}\right.$ : $8.83 \pm 1.20 \%)$, while groups $\mathrm{B}\left(\mathrm{HbA}_{10}: 5.55 \pm 0.19 \%\right)$ and $\mathrm{D}$ $\left(\mathrm{HbA}_{1 \mathrm{c}}: 8.51 \pm 1.09 \%\right)$ were kept overnight on long-acting insulin without feed-back control of blood glucose before euglycaemic clamping. Thereby, pre-equilibration of blood glucose at $6.7 \mathrm{mmol} / 1$ was shown to normalize basal hepatic glucose production (A: $2.27 \pm 0.48 ;$ C $2.50 \pm 0.57 \mathrm{mg}$. $\left.\mathrm{kg}^{-1} \cdot \min ^{-1}\right)$ despite different $\mathrm{HbA}_{1 \mathrm{c}}$ values, whereas basal
\end{abstract}

hepatic glucose production stayed elevated in groups B $\left(3.09 \pm 0.38 \mathrm{mg} \cdot \mathrm{kg}^{-1} \cdot \mathrm{min}^{-1}\right)$ and D $(3.21 \pm 0.58 \mathrm{mg}$. $\mathrm{kg}^{-1} \cdot \min ^{-1}$ ) with poor actual glycaemia (B: $10.9 \pm 4.6$; D: $12.1 \pm 4.6 \mathrm{mmol} / \mathrm{l})$. To restitute peripheral glucose utilisation close to normal (healthy subjects: $13.99 \pm 2.13$; A: $12.12 \pm$ 2.67; B: $8.72 \pm 3.0$; C: $10.27 \pm 1.69 ; \mathrm{D}: 7.10 \pm 2.31 \mathrm{mg} \cdot \mathrm{kg}^{-1}$. $\mathrm{min}^{-1}$; healthy subjects vs A: NS; healthy subjects vs B, C, D: $p<0.05)$ both long-term $\left(\mathrm{HbA}_{1 c}<5.8 \%\right)$ and acute nearnormoglycaemia by $12-\mathrm{h}$ i.v. insulin pre-treatment were required (group A). We conclude that good long-term glucose control per se is unable to normalize hepatic and peripheral glucose metabolism in Type 1 diabetic patients unless actual near-normoglycaemia is provided consistently, e.g. by i.v. overnight infusion of regular insulin.

Key words: Type 1 (insulin-dependent) diabetes mellitus, insulin resistance, euglycaemic hyperinsulinaemic clamp, intensified insulin therapy, $\mathrm{HbA}_{1 \mathrm{c}}$, near-normoglycaemia, continuous insulin infusion.
Impairment of hepatic and peripheral glucose metabolism is a common finding in Type 1 (insulin-dependent) diabetes mellitus despite insulin replacement [1-3]. Such insulin resistance is related to duration of the disease [47] and improves after tight glycaemic control [8-11], which may be achieved by "functional" insulin replacement providing $\mathrm{HbA}_{1 \mathrm{c}}$ within the normal range $(<5.8 \%)$ in about $40 \%$ of Type 1 diabetic patients [12]. That outcome, however, does not imply normalization of glucose metabolism. Thus, basal hepatic glucose production has been reported to be increased during fasting hyperglycaemia and hypoinsulinaemia in Type 1 diabetes vs healthy subjects $[1,2,13]$ by $12 \mathrm{~h}$ after injection of long-acting insulin despite well-controlled $\mathrm{HbA}_{1 \mathrm{c}}$ levels. Since any insulin-deficient state affects actual insulin sensitivity, this study aimed at evaluation of the metabolic impact of both long-term ( $>12$ months) nearnormoglycaemia $\left(\mathrm{HbA}_{1 \mathrm{c}}<5.8 \%\right)$ and of "acute" tight overnight blood glucose-control by i.v. infusion of regular insulin on hepatic glucose production (HGP) and peripheral glucose utilisation (M-values) in Type 1 diabetes. In this context, short-term fluctuations in blood glucose were demonstrated to exert a major impact on glucose turnover even in otherwise well-controlled Type 1 diabetic patients.

\section{Subjects and methods}

Type 1 diabetic patients ( 20 males, 12 females) without C-peptide release following $\mathrm{i}$. $\mathrm{v}$. arginine administration $(30 \mathrm{~g}, \mathrm{t}=30 \mathrm{~min})$ were included into the study. Duration of disease was longer than 3 years. None of the patients had evidence of renal or hepatic disease on routine laboratory examination, none was anaemic. All patients were trained to use a multiple insulin injection regimen employing the basal-bolus principle and blood glucose self control ( $n>4$ per day), and algorithms derived from physiological knowledge [12]. Such functional insulin therapy (FIT) substitutes basal insulin by s.c. long- 
Table 1. Clinical characteristics of healthy subjects and Type 1 diabetic patients (mean \pm SD)

\begin{tabular}{|c|c|c|c|c|c|c|}
\hline Group & $\begin{array}{l}(n) \\
\text { (male/ } \\
\text { female) }\end{array}$ & $\begin{array}{l}\text { Age } \\
\text { (years) }\end{array}$ & $\begin{array}{l}\text { BMI } \\
\left(\mathrm{kg} / \mathrm{m}^{2}\right)\end{array}$ & $\begin{array}{l}\text { Diabetes } \\
\text { duration } \\
\text { (years) }\end{array}$ & $\begin{array}{l}\text { Insulin } \\
\text { dose } \\
\text { (U/day) }\end{array}$ & $\begin{array}{l}\mathrm{HbA}_{1 \mathrm{c}} \\
(\%)^{\mathrm{b}}\end{array}$ \\
\hline \multicolumn{7}{|c|}{ Type 1 diabetic patients } \\
\hline $\mathrm{B}\left(\mathrm{Hb} \mathrm{A}_{\mathrm{Ic}}<5.8\right)$ & $6 / 2$ & $29.0 \pm 8.2$ & $23.2 \pm 2.4$ & $9.8 \pm 8.4$ & $50.0 \pm 11.3$ & $5.6 \pm 0.2$ \\
\hline $\mathrm{C}\left(\mathrm{HbA}_{\mathrm{lc}}>7.5\right)$ & $3 / 5$ & $34.3 \pm 17.9$ & $22.6 \pm 1.3$ & $12.3 \pm 6.8$ & $49.0 \pm 15.6$ & $8.8 \pm 1.2^{a}$ \\
\hline $\mathrm{D}\left(\mathrm{HbA}_{1 \mathrm{c}}>7.5\right)$ & $5 / 3$ & $34.6 \pm 16.7$ & $22.7 \pm 1.8$ & $9.9 \pm 6.0$ & $51.5 \pm 14.2$ & $8.5 \pm 1.1^{\mathrm{a}}$ \\
\hline Healthy subjects ${ }^{c}$ & $8 / 0$ & $23.9 \pm 0.7$ & $22.6 \pm 0.2$ & 0 & 0 & $<5.8 \%$ \\
\hline
\end{tabular}

${ }^{a} p<0.001$ vs healthy subjects. ${ }^{b} \mathrm{HbA}_{1 \mathrm{c}}$ measured on day of clamp study. ${ }^{\circ}$ Data from Hother-Nielsen et al. [17]

Grouping according to constancy of $\mathrm{HbA}_{\mathrm{lc}}$ values for at least 12 months

Table 2. Metabolic characteristics (plasma glucose $[\mathrm{PG}]$ and serum insulin) in the basal state and during an euglycaemic clamp (10 $\mathrm{mU} \cdot \mathrm{kg}^{-1}$. $\min ^{-1}$ ) in Type 1 diabetic patients $\left(n=8\right.$ each) with $\mathrm{HbA}_{1 c}<5.8 \%$ (groups $\mathrm{A}$ and $\mathrm{B}$ ) and $>7.5 \%$ (groups $\mathrm{C}$ and D) as well as in healthy subjects $(n=8)$

\begin{tabular}{|c|c|c|c|c|c|c|}
\hline \multirow[b]{2}{*}{ Group } & \multicolumn{3}{|l|}{ Basal state } & \multicolumn{3}{|c|}{ Euglycaemic clamp } \\
\hline & $\begin{array}{l}\text { Plasma glucose } \\
(\mathrm{mmol} / \mathrm{l})\end{array}$ & $\begin{array}{l}\text { Insulin } \\
(\mathrm{mU} / \mathrm{l})\end{array}$ & $\begin{array}{l}\text { PG/insulin } \\
\cdot 10^{-9}\end{array}$ & $\begin{array}{l}\text { SSI } \\
(\mathrm{mU} / 1)\end{array}$ & $\begin{array}{l}\text { MCR-insulin } \\
(\mathrm{ml} / \mathrm{kg} \cdot \mathrm{min})\end{array}$ & $\begin{array}{l}\text { SSPG } \\
(\mathrm{mmol} / \mathrm{l})\end{array}$ \\
\hline
\end{tabular}

$\mathrm{PG}:{ }^{\mathrm{a}} p<0.05$ vs healthy subjects

Insulin; PG/Insulin; SSI; MCR: Healthy subjects vs A, B, C, D: NS.
SSI, Steady-state serum insulin; PG/IRI ratio in molarities; MCR-insulin, metabolic clearance rate of insulin; SSPG, steady-state plasma glucose concentrations during euglycaemic clamp acting insulin ( $\mathrm{Zn-}$ or NPH-insulin) twice daily and uses regular insulin both preprandially and for correction of aberrant selfmeasured blood glucose values. No patient used an insulin pump for insulin replacement. Patients were trained in FIT during a 10-day hospitalisation period and requested to record self-measured blood glucose, daily carbohydrate intake and the amount of administered insulin. Consultations at the diabetes outpatient service were scheduled at 3-month intervals.

After displaying constancy of $\mathrm{HbA}_{1 \mathrm{c}}$ values over at least 12 months the patients were grouped ( $n=8$ each) $\mathrm{A}$ and $\mathrm{B}$ $\left(\mathrm{HbA}_{1 \mathrm{c}}<5.8 \%\right)$ and $\mathrm{C}$ and $\mathrm{D}\left(\mathrm{HbA}_{1 \mathrm{c}}>7.5 \%\right)$, respectively, and matched for age, body mass index $\left(\mathrm{kg} \cdot \mathrm{m}^{-2}\right)$ and duration of diabetes (Table 1). Subsequently, the groups were randomized ( $n=8$ each) either to pre-treatment with a variable overnight i.v. infusion of regular insulin (1-3 U/h) aiming at constant blood glucose concentration of less than $6.7 \mathrm{mmol} / \mathrm{l}(<120 \mathrm{mg} / \mathrm{dl})$ for at least $6 \mathrm{~h}(\mathrm{~A}$ and $\mathrm{C}$ ), or to administration of long-acting NPH-insulin the last dose given at 20.00 hours without overnight feedback control of blood glucose (B and D). Five patients of groups B ( 1 male, 1 female) and $\mathrm{D}$ ( 3 male) receiving long-acting insulin only, agreed to be re-examined also following overnight insulin infusion. Control subjects were non-obese, healthy males without any disturbance in glucose metabolism or family history of diabetes (Table 1).

All subjects were consuming a weight-maintaining diet containing at least $200 \mathrm{~g}$ carbohydrate per day. No drugs, with the exception of insulin, were permitted within 1 week prior to the clamp study. All subjects were requested to refrain from strenuous physical exercise at least 3 days prior to the study. Patients and healthy subjects were admitted to the metabolic ward on the evening prior to their clamp study, which was performed at 08.00 hours after a 12 -h overnight fast. The purpose, nature and potential risks of the study were carefully explained to all subjects before their consent to participate was obtained. The protocol was approved by the ethics committee of the hospital.

\section{Methods}

Clamp technique Euglycaemic insulin clamps were performed using a primed continuous insulin infusion (Actrapid HM U40; Novo-Nordisk, Gentofte, Denmark; $10 \mathrm{mU} \cdot \mathrm{kg}^{-1} \cdot \mathrm{min}^{-1}$ ) from 0 to $120 \mathrm{~min}[14,15]$. Arterialized venous blood samples were drawn at 5min intervals from an indwelling catheter inserted retrogradely into a wrist vein with the hand placed in a heating box maintained at $70^{\circ} \mathrm{C}$. Hepatic glucose production (HGP) was estimated by radioisotopic dilution technique with a primed continuous infusion of $3{ }^{3} \mathrm{H}$ glucose $(1 \mu \mathrm{Ci} / \mathrm{ml}, 50 \mu \mathrm{Ci}$ bolus: DuPont-NEN, Boston, Mass, USA) given at a steady rate of $24 \mathrm{ml} / \mathrm{h}$ from $-180 \mathrm{~min}$ to the end of the euglycaemic clamp study (+ $120 \mathrm{~min})$.

No estimates of hepatic glucose production were obtained in healthy control subjects as infusion of tritiated label is illegal in healthy subjects in Austria. However, since hepatic glucose production is suppressed by $90 \%$ when plasma insulin concentration is raised beyond $50 \mathrm{mU} / \mathrm{[}[16]$ the glucose infusion rate during a $10 \mathrm{mU}$ euglycaemic clamp gives a fair estimate of glucose utilisation in healthy non-diabetic subjects. Patients' rates for basal hepatic glucose production were compared with those reported for healthy subjects by others [17] (Table 1). Blood samples for the determination of plasma concentrations of "free" insulin, C-peptide, and specific activity of $3{ }^{3} \mathrm{H}$-glucose were obtained before initiation of insulin infusion $\left(10 \mathrm{mU} \cdot \mathrm{kg}^{-1} \cdot \mathrm{min}^{-1}\right)$ and at 10 -min intervals during the euglycaemic clamp. The coefficient of variation of blood glucose levels during the $10-\mathrm{mU}$ clamp period was $4.9 \pm 2.2 \%$ and has been determined at three 20 -min intervals during the second hour of the euglycaemic clamp.

Analytical methods. Plasma glucose was measured by a Beckman Glucose Analyzer II (Fullerton, Calif., USA). "Free" serum insulin (IRI) and C-peptide were determined radioimmunologically [18, 19]. Tritiated glucose specific activity was determined by the Somo- 
gyi procedure using a Packard Tricarb scintillation counter (model 4640; Downers Grove, Ill., USA) after deproteinization of plasma by $\mathrm{Ba}(\mathrm{OH})_{2}$ and $\mathrm{ZnSO}_{4}$ followed by the evaporation of supernatant containing ${ }^{3} \mathrm{H}_{2} \mathrm{O}$ [20]. $\mathrm{HbA}_{1 \mathrm{c}}$ was quantified by microcolumn-chromatography (Biorad, Richmond, Calif., USA).

\section{Calculations}

Calculations of HGP were done using the non-steady-state equation of Steele [21] with negative values of HGP set at zero. Apparent glucose disposal rates $\left(\mathrm{M}\right.$-value, $\mathrm{mg} \cdot \mathrm{kg}^{-1} \cdot \mathrm{min}^{-1}$ ) were calculated as the sum of glucose infusion rate necessary to maintain euglycaemia and estimated HGP during the second hour of each euglycaemic clamp period. Apparent metabolic clearance rate (MCR) of insulin was calculated from constant insulin infusion rate $\left(\mathrm{mU} \cdot \mathrm{kg}^{-1} \cdot \mathrm{min}^{-1}\right)$ divided by the incremental plasma insulin concentration $(\mathrm{mU} / \mathrm{l})$ above basal at steady state [22]. Plasma insulin concentration was corrected for endogenous insulin secretion in healthy subjects as follows:

Insulin $=\mathrm{IRI}_{\text {steady state }}-\left[\mathrm{IRI}_{\text {basal }} \times \mathrm{CP}_{\text {steady state }} / \mathrm{CP}_{\text {basal }}\right]$

\section{Statistical analysis}

Data are presented as means \pm standard deviation (SD). Differences between groups were tested by one-way analysis of variance employing Tukey's multiple range procedure. In addition, the Wilcoxon 2-sample test and the Kruskall-Wallis test were used and interpreted descriptively. Multiple regression analysis was employed to test the association between independent and dependent variables. Intra-individual data were tested by two-sided paired, $t$-test. $P<0.05$ was considered significant.

\section{Results}

Fasting concentrations of plasma glucose and serum insulin before the clamp study (Table 2). Overnight insulin infusion was feedback controlled by measurements of plasma glucose at 1 -h intervals in groups $\mathrm{A}$ and $\mathrm{C}$ to maintain near-normoglycaemia during at least $6 \mathrm{~h}$ before the clamp study (plasma glucose: A, $6.3 \pm 1.1$; C, $6.6 \pm$ $1.2 \mathrm{mmol} / \mathrm{l}$; NS). Patients administering only long-acting insulin in the evening displayed hyperglycaemic plasma glucose-levels prior to the clamp study (B, 10.9 $\pm 4.6 ; \mathrm{D}$, $12.1 \pm 4.6 \mathrm{mmol} / 1)$. No difference was apparent in overnight insulin dose $(\mathrm{A}, 10.9 \pm 3.1 ; \mathrm{B}, 12.1 \pm 2.4 ; \mathrm{C}, 10.8 \pm 3.0$; $\mathrm{D}, 12.5 \pm 2.9 \mathrm{U}$ ) nor in basal serum free insulin concentrations between groups A, B, C and D. Therefore, the mean "plasma glucose/IRI"-ratio was somewhat, but not significantly higher in groups B and D than in groups A and C and in healthy subjects.

Euglycaemic clamp. During i. v. insulin infusion at a rate of $10 \mathrm{mU} \cdot \mathrm{kg}^{-1} \cdot \mathrm{min}^{-1}$ steady-state mean free serum insulin concentrations were not different between patient groups A, B, C and D (range, A: $1010 \pm 189$ to B: $1292 \pm$ $250 \mathrm{mU} / \mathrm{l} ; \mathrm{NS})$ and healthy subjects $(1054 \pm 179 \mathrm{mU} / \mathrm{l})$ revealing normal apparent MCR of exogenous insulin $\left(5.8 \pm 1.2 \mathrm{ml} \cdot \mathrm{kg}^{-1} \cdot \mathrm{min}^{-1}\right)$ in Type 1 diabetic patients (range, A: $5.5 \pm 1.5$ to B: $7.0 \pm 3.6 \mathrm{ml} \cdot \mathrm{kg}^{-1} \cdot \mathrm{min}^{-1}$ ) (Table 2). Fasting concentration of C-peptide was suppressed by $51 \%$ during induced hyperinsulinaemia in healthy subjects and unmeasureable $(<0.3 \mathrm{ng} / \mathrm{ml})$ in diabetic patients (data not shown).
Table 3. Specific activity ( $\mathrm{cpm} / \mathrm{mg}$ ) of glucose in basal state during estimation of hepatic glucose production and prior to the hyperinsulinaemic, euglycaemic clamp study in Type 1 diabetic patients with either basal normo- $(A, C)$ or hyperglycaemia $(B, D)$

\begin{tabular}{lllll}
\hline Time & group A & group B & group C & group D \\
\hline$-30 \mathrm{~min}$ & $2896 \pm 921$ & $1430 \pm 371$ & $2634 \pm 972$ & $1631 \pm 458$ \\
$-15 \mathrm{~min}$ & $2901 \pm 994$ & $1416 \pm 372$ & $2644 \pm 1000$ & $1634 \pm 468$ \\
$-10 \mathrm{~min}$ & $2949 \pm 940$ & $1406 \pm 368$ & $2652 \pm 967$ & $1621 \pm 422$ \\
$-5 \mathrm{~min}$ & $2927 \pm 989$ & $1406 \pm 373$ & $2736 \pm 1006$ & $1634 \pm 442$ \\
$0 \mathrm{~min}$ & $2946 \pm 1009$ & $1430 \pm 414$ & $2678 \pm 959$ & $1646 \pm 442$ \\
\hline
\end{tabular}

Basal hepatic glucose production (HGP) in groups $\mathrm{A}$ $\left(2.27 \pm 0.48 \mathrm{mg} \cdot \mathrm{kg}^{-1} \cdot \mathrm{min}^{-1}\right)$ and $\mathrm{C}(2.50 \pm 0.57 \mathrm{mg}$. $\mathrm{kg}^{-1} \cdot \mathrm{min}^{-1}$; A vs B, NS) was in accordance with data reported in healthy control subjects $(2.41 \pm 0.10 \mathrm{mg}$. $\left.\mathrm{kg}^{-1} \cdot \min ^{-1}\right) \quad[17]$, while that in groups $\mathrm{B}$ $\left(3.09 \pm 0.38 \mathrm{mg} \cdot \mathrm{kg}^{-1} \cdot \mathrm{min}^{-1}\right)$ and $\mathrm{D}(3.21 \pm 0.58 \mathrm{mg}$. $\mathrm{kg}^{-1} \cdot \min ^{-1} ; \mathrm{B}$ vs D, NS) was somewhat elevated (Fig. 1). Hepatic glucose production was, however, completely suppressed in all Type 1 diabetic patients during the $10 \mathrm{mU} \cdot \mathrm{kg}^{-1} \cdot \mathrm{min}^{-1}$ clamp and supraphysiological hyperinsulinaemia. During estimation of HGP all groups were equally in steady-state and the change in specific activity with time did not differ between groups (Table 3 ).

In parallel, insulin-stimulated peripheral glucose disposal ("M"-values) was identical between healthy subjects $\left(14.0 \pm 2.1 \mathrm{mg} \cdot \mathrm{kg}^{-1} \cdot \mathrm{min}^{-1}\right)$ and Type 1 diabetic patients maintaining normal $\mathrm{HbA}_{1 \mathrm{c}}$ and near-normoglycaemia during the second hour of the euglycaemic hyperinsulinaemic clamp (group A, $12.1 \pm 2.7 \mathrm{mg} \cdot \mathrm{kg}^{-1} \cdot \mathrm{min}^{-1}$ ), but reduced
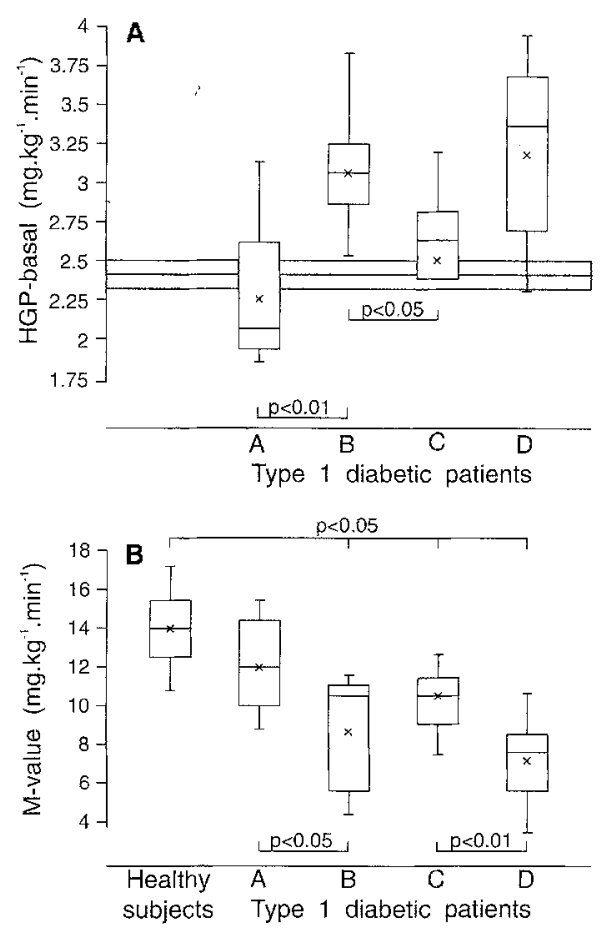

Fig. 1A, B Basal hepatic glucose production (A) and glucose utilisation ( $M$ values, $\mathbf{B}$ ) during an euglycaemic hyperinsulinaemic clamp (10 $\mathrm{mU}$ insulin $\left.\cdot \mathrm{min}^{-1} \cdot \mathrm{kg}^{-1}\right)$ in Type 1 diabetic patients with normal $(<5.8 \%$, groups $\mathrm{A}$ and $\mathrm{B})$ and elevated $\mathrm{HbA}_{\mathrm{tc}}(>7.5 \%$, groups $C$ and $D$ ), and in healthy subjects (shaded area) 

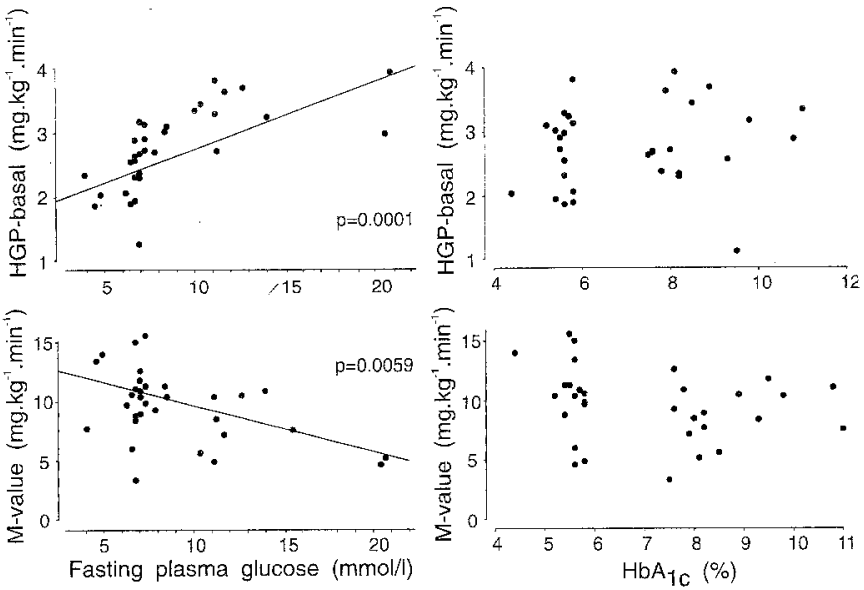

Fig. 2. Relation between glucose turnover (hepatic glucose production [HGP] and glucose utilisation [M-value]) and fasting plasma glucose as well as $\mathrm{HbA}_{1 \mathrm{c}}$ in Type 1 diabetes
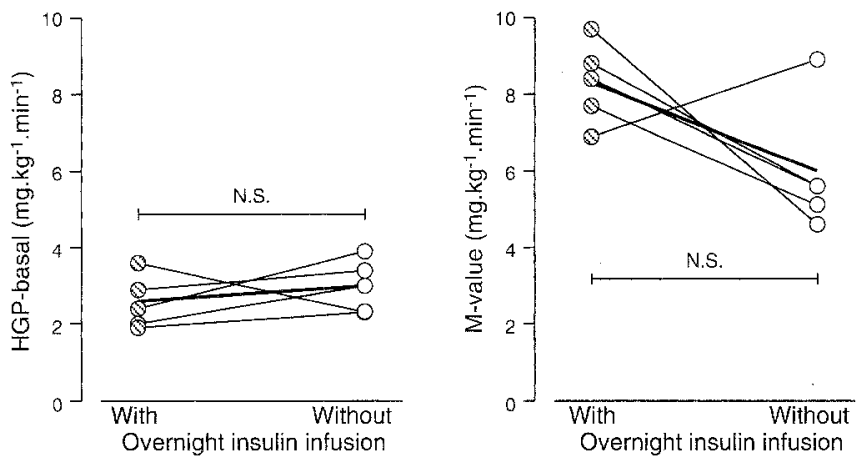

Fig. 3. Basal hepatic glucose production and $M$ values during an euglycaemic hyperinsulinaemic clamp $\left(10 \mathrm{mU}\right.$ insulin $\left.\cdot \mathrm{kg}^{-1} \cdot \mathrm{min}^{-1}\right)$ in five patients (four male, one female) of groups $\mathrm{B}(n=2)$ and $\mathrm{D}$ $(n=3)$ with either overnight $\mathrm{NPH}$-insulin or i.v. infusion of regular insulin

in those with elevated fasting plasma glucose (group B, $8.7 \pm 3.0 \mathrm{mg} \cdot \mathrm{kg}^{-1} \cdot \mathrm{min}^{-1} ; p<0.05 ;$ group D, $7.1 \pm 2.3 \mathrm{mg}$. $\mathrm{kg}^{-1} \cdot \mathrm{min}^{-1}$ ) or elevated $\mathrm{HbA}_{1 \mathrm{c}}$ (group C, $10.3 \pm 1.7 \mathrm{mg}$. $\mathrm{kg}^{-1} \cdot \min ^{-1}, p<0.05$ by Tukey's multiple range procedure) (Fig. 1).

By multiple regression analysis and testing for associations between independent (basal plasma glucose concentration and $\mathrm{HbA}_{1 \mathrm{c}}$ ) and dependent (basal HGP and Mvalue) variables a strong influence was seen of basal plasma glucose on basal HGP $(p<0.0001)$ and M-values $(p<0.001)$, but not of $\mathrm{HbA}_{1 \mathrm{c}}$ (Fig. 2). No interdependence was seen by two-way ANOVA between basal plasma glucose concentration and $\mathrm{HbA}_{1 c}$ in groups $\mathrm{A}$ and $\mathrm{C}$, which was due to normalization of basal plasma glucose by overnight i.v. insulin.

In the five patients receiving in randomized order both overnight i.v. regular insulin and s.c. long-acting insulin mean basal HGP differed between the two modes of insulin administration by $14 \%$ (s.c., $2.99 \pm 0.71$; i.v. $2.58 \pm 0.69 \mathrm{mg} \cdot \mathrm{kg}^{-1} \cdot \mathrm{min}^{-1}$, NS; $\left.p=0.44\right)$, and mean $\mathrm{M}$ value by $38 \%$ (s.c., $5.9 \pm 1.71$; i.v., $8.31 \pm 1.07 \mathrm{mg} \cdot \mathrm{kg}^{-1}$. $\min ^{-1}, \mathrm{NS} ; p=0.12$ ) (Fig. 3). In parallel, mean fasting plasma glucose was reduced by $60 \%$ from $13.2 \pm 6.9 \mathrm{mmol} / \mathrm{l}$ to
$5.2 \pm 1.1 \mathrm{mmol} / 1$ after overnight i.v. insulin, while fasting serum free insulin concentrations were within the same range (s.c., $11.2 \pm 6.4 \mathrm{mU} / \mathrm{l}$; i.v., $9.1 \pm 4.0 \mathrm{mU} / \mathrm{l}$ ) prior to the clamp study.

\section{Discussion}

This study compared the impact of short-term overnight (groups $\mathrm{A}$ and $\mathrm{C}$ ) strict plasma glucose control (mean range, 6.3 to $6.6 \mathrm{mmol} / \mathrm{l}$ ) by i. v. insulin vs that of poor control (mean range, 10.9 to $12.1 \mathrm{mmol} / \mathrm{l}$ ) by s.c. long-acting insulin with the last dose given $12 \mathrm{~h}$ before the euglycaemic clamp study (groups B and D) on HGP and peripheral glucose utilisation in Type 1 diabetic patients with either normal $(<5.8 \%)$ or elevated $(>7.5 \%)$ $\mathrm{HbA}_{1 \mathrm{c}}$. Thereby, both good and poor metabolic control was induced in the presence of either normal (groups A and $\mathrm{B}$ ) or elevated $\mathrm{HbA}_{1 \mathrm{c}}$ (groups $\mathrm{C}$ and $\mathrm{D}$ ) values. To saturate the capacity of peripheral glucose uptake as displayed by M-values and to suppress hepatic glucose production completely, hyperinsulinaemia in excess of $1000 \mathrm{mU} / 1$ was induced by a $10 \mathrm{mU}$ euglycaemic hyperinsulinaemic clamp.

Since hepatic glucose overproduction is regarded as an important factor in fasting hyperglycaemia in diabetes [1, $2,13]$ any abnormality in hepatic insulin sensitivity may be of clinical importance [3]. Against this background it is of note that in this study basal HGP was increased only during fasting hyperglycaemia (groups B and D) but not in Type 1 diabetic patients with strict glycaemic control (groups A and C) whose basal HGP stayed within the normal range [17] despite almost identical basal serum insulin concentrations. Such apparent insensitivity to insulin action may, however, also be due to differences in overnight plasma free-insulin profiles following s.c. (groups B and D) and i.v. insulin administration (groups $A$ and C). Since hyperglycaemia inhibits HGP in normal subjects [23], elevated basal HGP seems to reflect also some degree of "hepatic glucose resistance" in groups B and D $(p<0.05$ vs A and C) displaying basal hyperglycaemia. Such hepatic glucose resistance is, however, unrelated to long-term glycaemic control as no difference in HGP was seen between groups $\mathrm{A}\left(\mathrm{HbA}_{1 \mathrm{c}}<5.8 \%\right)$ and $\mathrm{C}\left(\mathrm{HbA}_{1 \mathrm{c}}>\right.$ $7.5 \%$ ) when plasma glucose was kept at less than $6.7 \mathrm{mmol} / \mathrm{l})$. No additional differentiation between groups was seen following total suppression of HGP by exogenous hyperinsulinaemia in excess of $1000 \mathrm{mU} / \mathrm{l}$ as insulin exerts its physiologic inhibitory action on HGP at a much smaller concentration [1]. The observed superior role of fasting hyperglycaemia in the determination of HGP is of note since a greater than normal hepatic sensitivity towards insulin has been assumed in Type 1 diabetic patients [17] on the condition that insulin concentration in the portal vein is normally two-to four-fold higher than in peripheral arteries [24]. Such physiologic portal hyperinsulinaemia seems, however, to play only a limited role in the control of HGP since heterotopic pancreatic transplantation has been demonstrated to normalize HGP in Type 1 diabetes despite systemic delivery of insulin [25]. 
This also applies to s. c. insulin administration as used in this study.

Analysing peripheral glucose uptake (M-values) during the clamp study it appears that neither absolute hypoinsulinaemia, which was prevented by either s.c. longacting insulin (groups B and D) nor overnight regular i.v. insulin (groups A and C), causes peripheral insulin resistance but rather short-term hyperglycaemia, i.e. an acute increase in the glucose/insulin ratio. Thus, fasting glycaemia but not $\mathrm{HbA}_{1 \mathrm{c}}$ values was related inversely to $\mathrm{M}$ values $(p<0.001)$ and directly to HGP $(p<0.0001)$ for groups A, B, C and D. These findings are in line with the observation that fasting hyperglycaemia decreases glucose uptake in Type 1 diabetes [26] and determines blood glucose response to subsequent stress hormone exposure [27]. Similarly, correction of hyperglycaemia by 7 days of phlorizin administration has been shown to normalize peripheral insulin action in streptozotocin-diabetic rats, while low-dose insulin treatment at persistent hyperglycaemia was of no avail [28]. Failure of normalization of fasting blood glucose to normalize glucose disposal in patients with poor $\mathrm{HbA}_{1 \mathrm{c}}$ value completely, however, suggests also a role for chronic hyperglycaemia in the development of insulin resistance.

Some data suggest that glucose "toxicity" [29] operates even in the presence of normal or elevated basal serum insulin concentration and prevents insulin action from returning to normal. From this a decisive role has to be attributed to "acute glucose toxicity" $[27,29,30]$ in the development of insulin resistance, which most likely results from any hyperglycaemic state, i.e. both in Type 1 and Type 2 diabetes. Such acute glucose toxicity impairs nonoxidative glucose disposal by $50 \%$ [31] and may well outweigh the influence of long-term tight blood glucose control as suggested by the failure of $\mathrm{HbA}_{1 \mathrm{c}}$ less than $5.8 \%$ to normalize HGP and/or glucose utilisation in this study unless fasting normoglycaemia was provided. Chronic nearnormoglycaemia seems, however, to contribute to normalization of glucose metabolism since $\mathrm{HbA}_{1 \mathrm{c}}$ less than $5.8 \%$ and concomitant fasting glycaemia less than $6.7 \mathrm{mmol} / \mathrm{l}$ were observed to maximally improve glucose utilisation and HGP in group A. Although the biochemical basis of hyperglycaemia-induced insulin resistance is still unclear, it may well be that acute hyperglycaemia reduces the total number of glucose transporters [32] by modification of their gene expression [33] or impaired intracellular activation [34]. Conversely, chronic hyperglycaemia may irreversibly affect target tissues of insulin action by glycosylation of regulatory peptides and enzymes and thereby impair post-receptor associated metabolic pathways [35]. The obtained data support the contention that impaired insulin action is an acquired feature depending more markedly on actual hyperglycaemia than on hypoinsulinaemia per se in Type 1 diabetes. Since Type 1 diabetic patients in groups A, B, C and D were matched for age, body mass index, duration of diabetes and daily insulin requirement other causes for differences in insulin sensitivity may be excluded. This also applies to insulin clearance, which did not differ between groups, and to insulin antibodies, which even at relatively high titre do not affect serum free insulin levels during an euglycaemic clamp study [19].
In conclusion, maintenance of long-term near-normal $\mathrm{HbA}_{1 \mathrm{c}}$ does not lead to normalization of hepatic and peripheral glucose turnover in Type 1 diabetes unless shorttime near-normoglycaemia is provided overnight by regular insulin for at least $6 \mathrm{~h}$. This outcome requires strategies of insulin therapy [12] aiming at normalization of blood glucose and not only of $\mathrm{HbA}_{1 \mathrm{c}}$ values. Such strategies, i. e. closed loop modes of insulin administration, will be more effective in improving glucose turnover and in avoiding impaired non-oxidative glucose disposal [31] than more conventional modes of insulin replacement, which are still accompanied by a high prevalence of late diabetic complications [36].

Acknowledgements. We are grateful to Ms A.Hofer and Ms A. Stockmayr for their skillful technical assistance and to Ms S. Hepfel for typing the manuscript.

\section{References}

1. DeFronzo RA, Hendler R, Simonson D (1982) Insulin resistance is a prominent feature of insulin-dependent diabetes. Diabetes 31: 795-801

2. DeFronzo RA, Simonson D, Ferrannini E (1982) Hepatic and peripheral insulin resistance: a common feature of type 2 (noninsulin-dependent) and type 1 (insulin-dependent) diabetes mellitus. Diabetologia 23: 313-319

3. Pedersen O, Beck-Nielsen H (1987) Insulin resistance and insulin-dependent diabetes mellitus. Diabetes Care 10: 516-523

4. Yki-Järvinen H, Koivisto VA (1986) Natural course of insulin resistance in type 1 diabetes. N Engl J Med 315: 224-230

5. Singh BM, Palma MA, Nattrass M (1987) Multiple aspects of insulin resistance. Comparison of glucose and intermediary metabolite response to incremental insulin infusion in IDDM subjects of short and long duration. Diabetes 36: 740-748

6. Nijs HGT, Radder JK, Fröhlich M, Krans HMJ (1988) Insulin action is normalized in newly diagnosed type 1 diabetic patients after three months of insulin treatment. Metabolism 37: 473-478

7. Nijs HGT, Radder JK, Fröhlich M, Krans HMJ (1989) The course and determinants of insulin action in type 1 (insulin-dependent) diabetes mellitus. Diabetologia 32: 20-27

8. Yki-Järvinen H, Koivisto VA (1984) Continuous subcutaneous insulin infusion therapy decreases insulin resistance in type 1. diabetes. J Clin Endocrinol Metab 58: 659-666

9. Lager I, Lönnroth P, Schenck H, Smith U (1983) Reversal of insulin resistance in type I diabetes after treatment with continuous subcutaneous insulin infusion. Br Med J 287: 1661-1664

10. Beck-Nielsen H, Richelsen B, Hasling C, Hother-Nielsen O, Heding L, Sorensen NS (1984) Improved in vivo insulin effect during continuous subcutaneous insulin infusion in patients with IDDM. Diabetes 33: 832-837

11. Arslanian S, Nixon PA, Becker D, Drash AL (1990) Impact of physical fitness and glycaemic control on in vivo insulin action in adolescents with IDDM. Diabetes Care 13: 9-15

12. WaldhäusI W (1986) The physiological basis of insulin treatment - clinical aspects. Diabetologia 29:837-849

13. Perriello G, DeFeo P, Torlone E et al. (1991) The dawn phenomenon in type 1 (insulin-dependent) diabetes mellitus: magnitude, frequency, variability and dependency on glucose counterregulation and insulin sensitivity. Diabetologia 34: 21-28

14. DeFronzo RA, Tobin JD, Andres R (1979) Glucose clamp technique: a method for quantifying insulin secretion and resistance. Am J Physiol 237: E214-E223

15. Bratusch-Marrain PR, Vierhapper H, Komjati M, Waldhäusl W (1985) Acetyl-salicylic acid impairs insulin-mediated glucose utilization and reduces insulin clearance in healthy and non-insulin-dependent diabetic man. Diabetologia 28: 671-676 
16. Bratusch-Marrain PR, Smith D, DeFronzo RA (1982) The effect of growth hormone on glucose metabolism and insulin secretion in man. J Clin Endocrinol Metab 55:973-982

17. Hother-Nielsen O, Schmitz O, Bak J, Beck-Nielsen H (1987) Enhanced hepatic insulin sensitivity, but peripheral insulin resistance in patients with type 1 (insulin-dependent) diabetes. Diabetologia 30: $834-840$

18. Waldhäusl WK, Bratusch-Marrain PR, Gasic S, Korn A, Nowotny $P$ (1979) Insulin production rate following glucose ingestion estimated by splanchnic C-peptide output in normal man. Diabetologia 17: 221-227

19. Waldhäusl W, Bratusch-Marrain PR, Kruse V, Jensen I, Nowotny $\mathrm{P}$, Vierhapper $\mathrm{H}$ (1985) Effect of insulin antibodies on insulin pharmacokinetics and glucose utilization in insulin dependent diabetic patients. Diabetes 34: 166-173

20. Somogyi M (1930) A method for the precipitation of blood filtrates for the determination of sugar. J Biol Chem 86: 655-663

21 . Steele R (1959) Influence of glucose loading and of injected insulin on hepatic glucose output. Ann N Y Acad Sci 82: 420-430

22. Waldhäusl WK, Gasic S, Bratusch-Marrain PR, Korn A, Nowotny $P$ (1982) Feedback inhibition by biosynthetic human insulin release in healthy human subjects. Am J Physiol 243: E476-E482

23. Sacca L, Hendler R, Sherwin R (1978) Hyperglycemia inhibits glucose production in man independent of changes in glucoregulatory hormones. J Clin Endocrinol Metab 47: 1160-1163

24. Blackard WG, Nelson NC (1970) Portal and peripheral vein immunoreactive insulin concentrations before and after glucose infusion. Diabetes 19: 302-306

25. Wilczek H, Gunnarsson R, Felig P, Östman J, Groth CG, Wahren $J$ (1991) Normalization of hepatic glucose regulation despite systemic insulin delivery. Studies in patients with pancreatic transplantation for type 1 (insulin-dependent) diabetes mellitus. Diabetologia 34: 345-349

26. Yki-Järvinen H, Helve E, Koivisto VA (1987) Hyperglycaemia decreases glucose uptake in type 1 diabetes. Diabetes 36: 892 896

27. Waldhäusl W, Bratusch-Marrain P, Komjati M, Breitenecker F, Troch I (1992) Blood glucose response to stress hormone exposure in healthy man and insulin dependent diabetic patients: prediction by computer modeling. IEEE Transactions on Biomedical Engineering 39: 779-790
28. Lisato G, Cusin I, Tiengo A, Del Prato S, Jeanrenaud B (1992) The contribution of hyperglycaemia and hypoinsulinaemia to the insulin resistance of streptozotocin-diabetic rats. Diabetologia $35: 310-315$

29. Unger RH, Grundy S (1985) Hyperglycemia as inducer as well as consequence of impaired islet cell function and insulin resistance: implications for the management of diabetes. Diabetologia 28: $119-121$

30. Yki-Järvinen H (1990) Acute and chronic effects of hyperglycaemia on glucose metabolism. Diabetologia 33: 579-585

31. Vuorinen-Markkola H, Koivisto VA, Yki-Järvinen H (1992) Mechanisms of hyperglycaemia-induced insulin resistance in whole body and skeletal muscle of type 1 diabetic patients. Diabetes 41: $571-580$

32. Hansen IL, Cryer PE, Rizza A (1985) Comparison of insulinmediated glucose disposal in patients with insulin-dependent diabetes mellitus and in nondiabetic subjects. Diabetes 34: 751 766

33. Kahn BB, Flier JS (1990) Regulation of glucose-transporter gene expression in vitro and in vivo. Diabetes Care 13:548-564

34. Baly DL, Horuk R (1987) Dissociation of insulin-stimulated glucose transport from the translocation of glucose carriers in rat adipose cells. J Biol Chem 262:21-24

35. Yki-Järvinen H, Sahlin K, Ren JM, Koivisto VA (1990) Localization of rate-limiting defect for glucose disposal in skeletal muscle of insulin-resistant type 1 diabetic patients. Diabetes 39: 157-167

36. Derfler K, Waldhäusl W, Zyman HJ, Howorka K, Holler C, Freyler H (1986) Diabetes care in a rural area: clinical and metabolic evaluation. Diabetes Care 9: 509-517

Received: 17 August 1992

and in revised form: 30 November 1992

Prof. W. Waldhäusl

Division of Endocrinology and Metabolism

Department of Medicine III

University of Vienna

Währinger Gürtel 18-20

A-1090 Wien

Austria 